\title{
Phyto-Synthesized Silver Nanoparticles using Leaves Extracts of Morus alba and Aegle marmelos Inhibited Fusarium Wilt and Charcoal Rot in Tomato
}

\author{
Naseem Hassan $^{1 \dagger}$, Hina Ashraf ${ }^{1 \dagger}$, Tehmina Anjum ${ }^{1 *}$ and Waheed Akram ${ }^{2}$ \\ ${ }_{1}^{1}$ Institute of Agricultural Sciences, University of the Punjab, Lahore-54590, Pakistan \\ ${ }^{2}$ Guangdong Key Laboratory for New Technology Research of Vegetables, Vegetable Research Institute, Guangdong \\ Academy of Agricultural Sciences, Guangzhou, China \\ *For correspondence: anjum.iags@pu.edu.pk; tehminaanjum@yahoo.com \\ Contributed equally to this work and are co-first authors \\ Received 26 May 2020; Accepted 05 August 2020; Published 10 December 2020
}

\begin{abstract}
Antifungal metal structures, using silver at nanoscale, were synthesized using leaves extract of two indigenous trees i.e., Morus alba (white mulberry) and Aegle marmelos (bael fruit). The antifungal characteristics of synthesized silver nanoparticles (AgNPs) was verified against Fusarium oxysporum, the causal agent of Fusarium wilt and Macrophomina phaseolina, the pathogen of charcoal rot, taking tomato as a model plant. Synthesized nanoparticles were checked against selected fungi in concentrations of $25,50,75$ and $100 \mu \mathrm{g} / \mathrm{mL}$. Negative control received no nanoparticles but sterilized water, whereas positive control plants were treated with chemical fungicide (Nativo). Result of in vitro and greenhouse experiments confirmed the potential of synthesized nanoparticles to reduce fungal growth and disease incidence. However, the NPs synthesized using leaves extract of white mulberry were more effective. In green house trials, the plants treated with NPs in a concentration of $100 \mu \mathrm{g} / \mathrm{mL}$ showed parallel results as were recorded in plants receiving fungicide. Similarly, both selected fungi also depicted slight variation in their responses towards various treatments as percentage of growth inhibition as well as disease incidence was more in $F$. oxysporum than in $M$. phaseolina. UV-spectrophotometer ascertained the optimization conditions by adjusting concentrations of silver nitrate between 1, 1.5, 2, 2.5 and $3 \mathrm{~m} M$, incubation period of 24, 48, 72 and 96 $\mathrm{h}$ and $\mathrm{pH}$ of biosynthesis system adjusted at 4, 6, 8, 10 and 12. FTIR confirmed the presence of different functional groups available both in plant extracts and nanoparticles while, SEM indicated spherical, polydisperse morphology of AgNPs with size ranges from 20-48 nm respectively. In pot experiment nanoparticles synthesized using white mulberry leaves reduced fusarium infection up to $97 \%$ and macrophomina rot up to $92 \%$. Nanoparticles synthesized using bael leaves extract were comparatively less effective against selected fungi than those synthesized using white mulberry leaves extract. Hence these results provided basis for the use of green synthesized NPs using white mulberry leaves extract as an alternative to conventional fungicides to help reduce environmental pollution. (C) 2021 Friends Science Publishers
\end{abstract}

Keywords: Silver nanoparticles; Green synthesis; Fusarium wilt; Charcoal rot; Tomato

\section{Introduction}

Soil borne pathogens affect crop plants in different ways, resulting in heavy yield losses. The diseases caused by these microbes are often very difficult to manage because of their heterogeneous incidence. Mostly soil borne pathogens can survive in soil for long periods even in the absence of their host (Veena et al. 2014). These pathogens have a wide host range and chemicals often do not work well on these culprits (Veena et al. 2014). With over 120 strains, F. oxysporum Schlecht. emend. Snyder \& Hansen is one of the most commonly occurring fungal pathogens in soil responsible for wilt in a range of agronomic and horticultural crops
(Michielse and Rep 2009). Macrophomina phaseolina (Tassi) Goid. is another common soil borne fungi that is known to infect 500 plants belonging to 100 different plant families (Srivastava and Singh 1990). Both these pathogens are known to reduce yield in different crops between 30 80\% (Mayek-Perez et al. 2003; Arturo and Karla 2017). Use of fungicides is a general method to control these pathogens. However, development of resistance in pathogen due to multiple applications of these fungicides; increasing awareness regarding effect of fungicidal residues on our ecosystem and human beings has lead researchers to focus on finding safe alternatives to reduce yield losses and to increase food security (Zubrod et al. 2019).

To cite this paper: Hassan N, H Ashraf, T Anjum, W Akram (2021). Phyto-synthesized silver nanoparticles using leaves extracts of Morus alba and Aegle marmelos inhibited fusarium wilt and charcoal rot in tomato. Intl J Agric Biol 25:165-172 
Nanotechnology refers to the science of nanoscale objects that has been listed in European Commission's six "Key Enabling Technologies" recognised for their role in sustainable competitiveness and growth in various fields of industrial applications (EC 2012). Beside its known applications in the fields of medicine, environmental sciences, bio-engineering; cosmetics and other industries, nanotechnology possesses a range of potential applications for agriculture stor too. This has led to intense research on the use of nanotechnology in solving agricultural problems both at academic and industrial levels (Chen and Yada 2011; Dasgupta et al. 2015; Parisi et al. 2015). Special emphasis has been given to the development of nanoproducts for disease management and nano-fertilizers for improving soil fertility (Tolaymat et al. 2017). The uniqueness lies in the physical and chemical properties of NPs that includes their nano size, shape, increased surface area and catalytic reactivity that has opened new paradigms for agricultural sector.

Usually nanoparticles are synthesized through reduction reactions using different reducing agents as tollens reagent, ascorbate, elemental hydrogen, sodium citrate etc. to reduce silver ions $\left(\mathrm{Ag}^{+}\right)$in the reaction mixture. For stabilization of synthesized NPs different polymeric compounds as poly vinyl alcohol is used (Merga et al. 2007; Erdogan 2020). This chemical approach is considered as an eco-unfriendly and expansive method for nanoparticles' synthesis. Green synthesis using biological systems as plants and microbes provides a sustainable alternative method to synthesize nanoparticles with minimized generated waste. The processes are reproducible, cost effective and simple. Plant extracts provides both stabilizing and reducing agents for the nanoparticles' synthesis.

Several workers have tried different phyto-extracts to synthesise NPs possessing antimicrobial properties. Phenolic acids like caffeine present in Camellia sinensis were utilized for the production and stabilization of AgNPs (VilchisNestor et al. 2008). Leaves extract of Camellia sinensis (black tea) also provided flavonoids and polyphenols for the formation of AgNPs (Begum et al. 2009). Huang et al. (2011) used Cacumen platyclade extract as a source of reducing sugars and flavonoids for reducing silver ions. The nanoparticles produced revealed substantial antibacterial activity against $S$. aureus and E. coli. Similarly, in a recent study Aritonang et al. (2019) used Impatiens balsamina and Lantana camara as a source for bioreducing agents and synthesized silver nanoparticles that were found active mutually against gram positive and gram-negative bacteria.

The present study explored the potential of two indigenous trees i.e., A. marmelos L Correa (bael fruit); and M. alba L. (white mulberry) for synthesizing AgNPs to manage soil borne pathogens in our cropping system. Bael fruit belongs to the family Rutaceae and is native to the subcontinent. The plant is a rich source of furocoumarins, flavonoids and alkaloids that are well known for medicinal properties. White mulberry, a member of family Moraceae is native to northern China and India. The plant is helpful in treatment of digestive problems like cough, hepatitis and dyspepsia (Babu and Ammani 2009).

Chemically synthesized metallic NPs are used to control soil borne diseases but these have some drawbacks; therefore, search of bioactive green synthesized NPs is direly needed. In this context the present study was designed to investigate the potential of indigenous plant extracts including bael fruit and white mulberry in synthesizing antifungal AgNPs to manage soil borne diseases in tomato crop.

\section{Materials and Methods}

\section{Preparation of phyto-extracts}

For green synthesis of AgNPs, leaves extract of bael fruit (A. marmelos L. Correa); and white mulberry (M. alba L.) was prepared. Diseased free, middle aged leaves of selected plants were collected, washed and dried under shade. Powdered dried leaves were soaked in water at the rate of $100 \mathrm{~g}$ in $200 \mathrm{~mL}$ sterilized deionized water. The mixture was heated in a water bath covered with a plastic bag at $90^{\circ} \mathrm{C}$ for $10 \mathrm{~min}$ followed by its cooling and filtration using Whatman filter paper no. 1. The extract obtained was kept at $4^{\circ} \mathrm{C}$ until further use.

\section{Synthesis of silver nanoparticles}

In a $100 \mathrm{~mL}$ conical flask, each phyto-extract $(5 \mathrm{~mL})$ was supplemented with $45 \mathrm{~mL}$ of $2.5 \mathrm{mM} \mathrm{AgNO}$. Sodium chloride (1 molar) was used to adjust $\mathrm{pH}$ of this solution to 8. After this the mixture was incubated in dark to prevent photo-activation of $\mathrm{AgNO}_{3}$. The solution changed its colour from colourless to brown because of the silver reduction.

\section{Optimized biosynthesis parameters for silver nanoparticles}

Synthesis of AgNPs $\left(\mathrm{AgNO}_{3}\right)$ was optimized at various conditions including: (i) concentration of silver nitrate i.e., $1,1.5,2,2.5$ and $3 \mathrm{~m} M$; (ii) incubation time i.e., 24, 48, 72 and $96 \mathrm{~h}$ and (iii) $\mathrm{pH}$ i.e., 4, 6, 8, 10 and 12. These conditions were optimized to get maximum synthesis of NPs as this can reduce time in collecting maximum possible quantities of NPs to be used in bioassays and characterization. The synthesis of AgNPs at various conditions was confirmed by UV-VIS absorption spectra.

AgNPs synthesized using white mulberry plants showed maximum absorption peak at $2.5 \mathrm{~m} M$ of silver nitrate after $48 \mathrm{~h}$ of incubation and at $\mathrm{pH} 8$. Whereas, in case of bael fruit maximum absorption was recorded at $2 \mathrm{mM}$ of silver nitrate after $72 \mathrm{~h}$ of incubation at $\mathrm{pH} 10$.

\section{Sample preparation for AgNPs characterization}

The synthesized nanoparticles' solution was centrifuged at $6000 \mathrm{rpm}$ for $30 \mathrm{~min}$ at $4^{\circ} \mathrm{C}$. The supernatant was discarded 
and pellet was transferred to a china dish using deionized water. The material was dried by placing these china dishes in a hot air oven at $40^{\circ} \mathrm{C}$ for fortnight. The parched surface was scratched and stored for further characterization.

\section{Characterization of synthesized AgNPs}

The synthesis of AgNPs was determined through UV-VIS spectrophotometer (DeNovix DS-11). The absorption spectrum was taken between 200-800 nm. Fourier Transform Infrared (FTIR) spectra were acquired using Nicolet 800 spectrophotometer in concurrence with MTech PAS cell. The spectra were recorded between at $4-6 \mathrm{~cm}^{-1}$ with a resolution average of 128 scans. Magnesium perchlorate was used as the drying agent, whereas, in PAS cell Helium gas was used. SEM micrographs were obtained using scanning electron microscope with $25 \mathrm{kV}$ accelerating voltage. Thin films of the samples were prepared using carbon coated grid. For this the prepared samples were dropped on the gird in a very small amount followed by removal of the extra solution using blotting paper. Prepared thin films were dried by placing them under mercury lamp for 5-6 min.

\section{In vitro antifungal assay}

Antifungal activity of synthesized nanoparticles was investigated against two soil borne phytopathogenic fungi i.e., M. phaseolina (Tassi) Goid. and F. oxysporumi (Sacc.) W.C. Snyder \& H.N. Synthesized nanoparticles were added in Malt Extract Agar (MEA) media in different concentrations of $25,50,75,100 \mu \mathrm{g} / \mathrm{mL}$. All treatments were replicated thrice where control received no NPs. The selected fungi were inoculated in the centre of each media plate followed by their incubation at $25 \pm 1{ }^{\circ} \mathrm{C}$ for seven days. The antifungal activity was recorded in terms of fungal growth inhibition in treatments in comparison to the control. The assay was performed in completely randomized design.

\section{In vivo antifungal assay}

The effectivity of synthesized NPs was checked through a greenhouse trial. Earthen pots of $\sim 25 \mathrm{~cm}$ diameter were filled with sandy loam soil containing $0.69 \%$ organic matter; 6.3 ppm available phosphorus; 100 ppm available potassium and $\mathrm{pH}$ 7.8. The soil was treated with methylene bromide for sterilization and leaving for 4 days to eliminate residues of methylene bromide. Conidial suspensions of $F$. oxysporum and $M$. phaseolina adjusted at final concentration of $10^{6}$ spores/ $\mathrm{mL}$ were prepared in distilled water and added at the rate of $30 \mathrm{~mL}$ per pot. Roots of 20 days old tomato (Solanum lycopersicum variety Rio Grande) plants were dipped in a concentration range of synthesized AgNPs i.e., 25, 50, 75 and $100 \mu \mathrm{g} / \mathrm{mL}$ for $2 \mathrm{~h}$. Roots of the negative control plants was dipped in sterilized water and those of positive control were dipped in fungicide (Nativo) for same time period. Four plants in each pot were transferred. Each treatment was replicated thrice. Plants were fertilized after every two weeks with a 20:20:20 NPK soluble fertilizer (1 g/L) and the pots were irrigated with tap water when required. Hand weeding was done to remove any appearing weeds in pots. The plants were regularly checked for disease symptoms. The trial was conducted in a completely randomized design with three replications. After 6 weeks the plants were harvested and data for their root and shoot lengths; fresh and dry weights and disease incidence was taken. Disease incidence was calculated by diving number of infected plants by total number of plants and multiplying the resultant by 100 (Vincent 1947).

\section{Data analysis}

Collected data were statistically analysed using analysis of variance technique by statistical analysis software (SAS) and Microsoft Excel program. In case of significance, treatments means were separated using LSD (Least Significant Difference) test at $P \leq 0.01$.

\section{Results}

\section{Confirmation and characterization of silver nanoparticles}

A clear change in colour of the mixture (plant extract + $\mathrm{AgNO}_{3}$ ) was recorded in both plant extracts. Also, appearance of a clear peak after $400 \mathrm{~nm}$ in both cases i.e., at $413 \mathrm{~nm}$ for the extract of white mulberry (Fig. 1A) and at $410 \mathrm{~nm}$ for bael fruit (Fig. 1B) also confirmed presence of AgNPs in both cases.

\section{In vitro antifungal bioassay}

Nanoparticles synthesized using plant extracts were checked for their potential to inhibit two soil borne fungi in invitro conditions. Silver NPs synthesized using both plant extracts significantly reduced growth of the tested fungi (Fig. 2). However, NPs prepared from the extract of white mulberry leaves extract showed better inhibition in comparison to the NPs prepared using extract of bael fruit (Fig. 2). The percentage of inhibition increased with increase in concentration of NPs used. Among the two selected soil borne fungi, $F$. oxysporum showed more inhibition percentages when compared to the $M$. phaseolina. The highest tested concentration of NPs i.e., $100 \mu \mathrm{g} / \mathrm{mL}$, synthesised from leaves extract of white mulberry decreased growth of $F$. oxysporum by $84 \%$ and of $M$. phaseolina by $77 \%$. Whereas, particles synthesized from leaves extract of bael fruit reduced mycelial growth up to $68 \%$ in $F$. oxysporum and $63 \%$ in $M$. phaseolina hence showed 14 $16 \%$ lower antifungal potential than leaves extract of white mulberry (Fig. 2). 

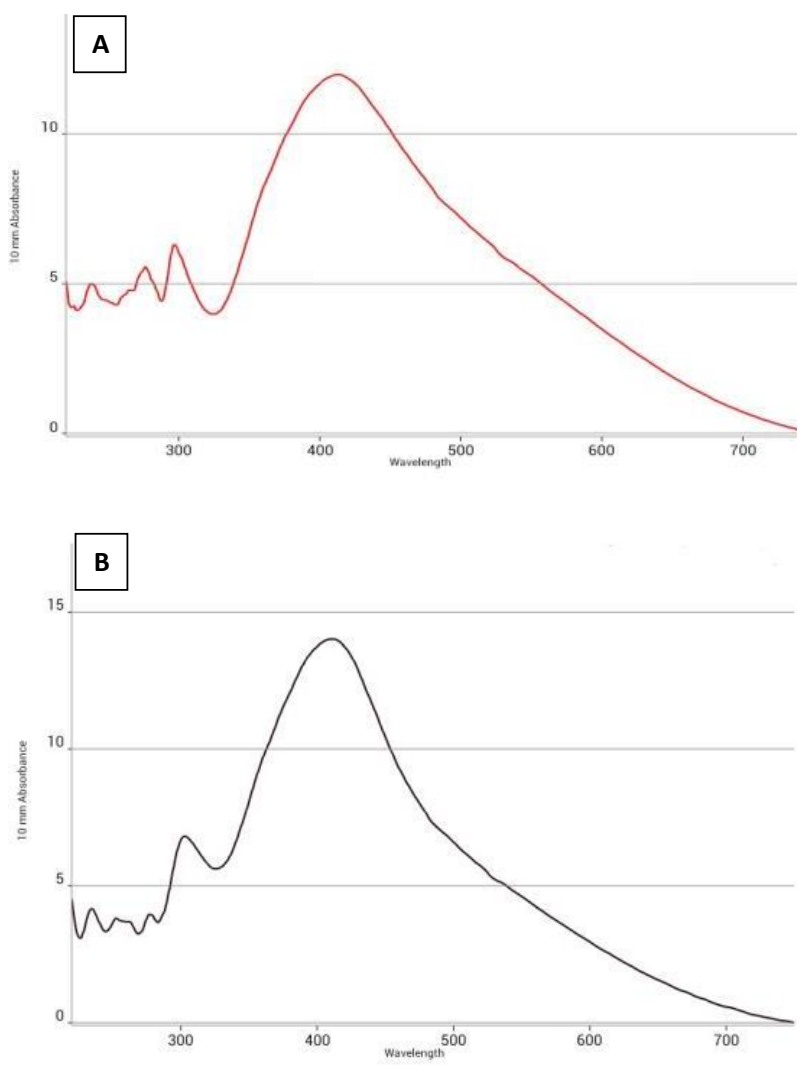

Fig. 1: UV-Vis graphs of AgNPs synthesized from leaves extract of A: M. alba; B: A. marmelos after incubation time of 48 hours, using $2.5 \mathrm{mM}$ of $\mathrm{AgNO}_{3}$ and at $\mathrm{pH} 8$

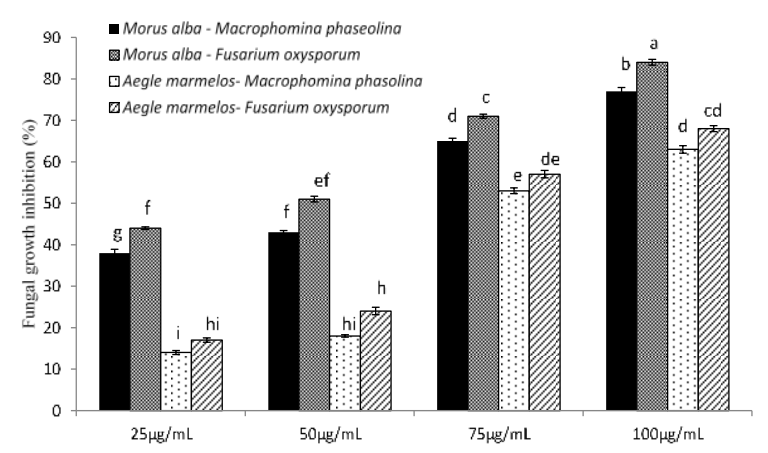

Fig. 2: In vitro effect of AgNPs synthesized using Morus alba and Aegle marmelos leaves extract in concentrations of 25, 50, 75, 100 $\mu \mathrm{g} / \mathrm{mL}$ against $F$. oxysporum and $M$. phaseolina. Vertical bars show standard error of means of three replicates. Means not sharing the same letters within a column differ significantly from each other at $P \leq 0.01$

\section{In vivo antifungal bioassay}

Results of greenhouse experiment also followed similar trend as was observed in in vitro assays (Fig. 3). Nanoparticles synthesized from white mulberry leaves extract decreased disease incidence more significantly than those synthesized using bael leaves extract. Highest disease reduction was

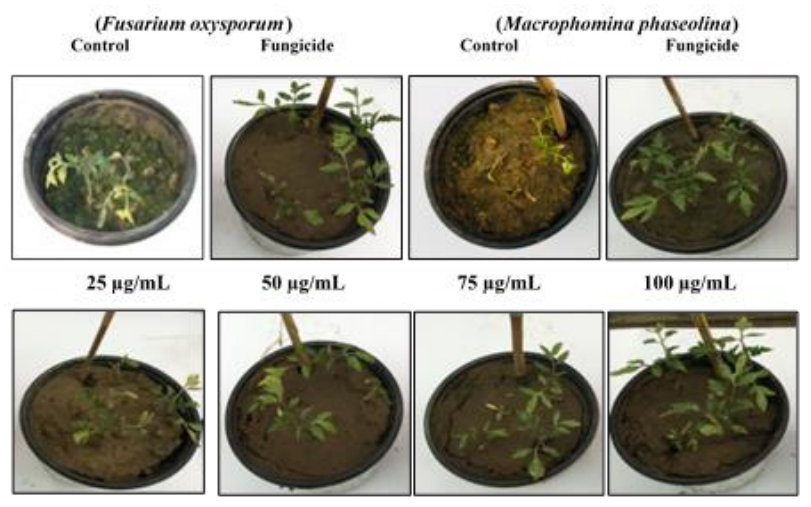

AgNPs synthesized using Morus alba leaves extract vs Fusarium oxysporum

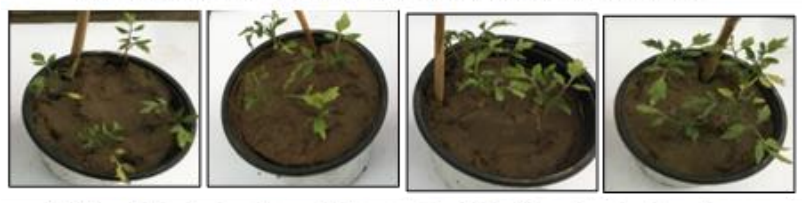

AgNPs synthesized using Morus alba leaves extract of vs Macrophomina phaseolina

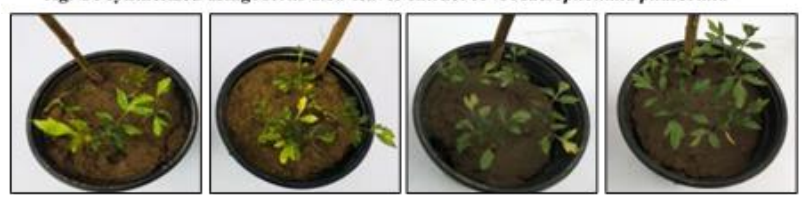

AgNPs synthesized using Aegle marmelos leaves extract vs Fusarium oxysporum

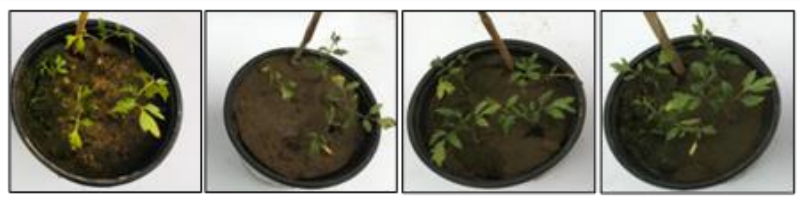

AgNPs synthesized using Aegle marmelos leaves extract vs Macrophomina phaseolina

Fig. 3: In vivo effect of various treatments on disease development in tomato pots

recorded at $100 \mu \mathrm{g} / \mathrm{mL}$ of NPs which was equivalent to the disease reduction of fungicide used. Nanoparticles extracted from white mulberry leaves decreased incidence of Fusarium wilt up to $96.99 \%$ when used in $100 \mu \mathrm{g} / \mathrm{mL}$. Nanoparticles synthesized using bael leaves extract reduced wilt by Fusarium up to $87.53 \%$ that is $9.46 \%$ lower than the AgNPs synthesized by using white mulberry leaf extract. Both of these treatments reduced infection by $M$. phaseolina by 92.39 and $81.58 \%$ respectively (Table 1). Reduction in disease incidence was found correlated with plant height and biomass confirming the positive effect of various treatments on crop health and physiology.

\section{Characterization of AgNPs synthesized using leaves extract}

FTIR analysis of leaves and NPs synthesized from $M$. alba: The possible biomolecules/phytochemicals present in white mulberry dried leaves and AgNPs biosynthesized using its leaves extract were identified through FTIR analysis (Fig. 4A and B). In case of dried leaves, the bands 
Antifungal Phyto-synthesized Silver Nanoparticles / Intl J Agric Biol, Vol 25, No 1, 2021

Table 1: In vivo effect of phyto-synthesized silver nanoparticles on disease development in tomato plants

\begin{tabular}{|c|c|c|c|c|c|c|c|c|}
\hline \multirow[t]{3}{*}{ Treatments } & \multicolumn{4}{|c|}{ Disease incidence $(\%)$} & \multicolumn{4}{|c|}{ Disease reduction (\%) } \\
\hline & \multicolumn{2}{|c|}{ M. alba AgNPs } & \multicolumn{2}{|c|}{ A. mamelosAgNPs } & \multicolumn{2}{|c|}{ M. alba AgNPs } & \multicolumn{2}{|c|}{ A. mamelos AgNPs } \\
\hline & F. oxysporum & M. phaseolina & F. oxysporum & M. phaseolina & F. oxysporum & M. phaseolina & F. oxysporum & M. phaseolina \\
\hline Control & $100 \mathrm{a}$ & $100 \mathrm{a}$ & $100 \mathrm{a}$ & $100 \mathrm{a}$ & - & - & - & - \\
\hline Fungicide & $5.33 \mathrm{e}$ & $7.58 \mathrm{~d}$ & $5.33 \mathrm{e}$ & $7.58 \mathrm{e}$ & $94.76 \mathrm{a}$ & $92.42 \mathrm{a}$ & $94.76 \mathrm{a}$ & $92.42 \mathrm{a}$ \\
\hline $25 \mu \mathrm{g} / \mathrm{mL}$ & $94.15 b$ & $97.06 \mathrm{a}$ & $98.04 \mathrm{a}$ & $99.15 \mathrm{a}$ & $5.85 \mathrm{~d}$ & $2.94 \mathrm{~d}$ & $1.96 \mathrm{e}$ & $0.85 \mathrm{e}$ \\
\hline $50 \mu \mathrm{g} / \mathrm{mL}$ & $73.28 \mathrm{c}$ & $80.18 b$ & $81.59 \mathrm{~b}$ & $86.63 b$ & $26.72 \mathrm{c}$ & $19.82 \mathrm{c}$ & $18.41 d$ & $13.37 \mathrm{~d}$ \\
\hline $75 \mu \mathrm{g} / \mathrm{mL}$ & $43.81 \mathrm{~d}$ & $52.83 \mathrm{c}$ & $55.58 \mathrm{c}$ & $63.51 \mathrm{c}$ & $56.19 b$ & $47.17 b$ & $44.42 \mathrm{c}$ & $36.49 \mathrm{c}$ \\
\hline \multirow[t]{2}{*}{ LSD value at $P \leq 0.01$} & 2.53 & 11.19 & 2.62 & 1.70 & 3.26 & 2.36 & 3.54 & 1.80 \\
\hline & \multicolumn{4}{|c|}{ Shoot length (cm) } & \multicolumn{4}{|c|}{ Root length (cm) } \\
\hline Control & - & - & - & - & - & - & - & - \\
\hline Fungicide & $38.62 \mathrm{a}$ & $35.85 b$ & $38.62 \mathrm{a}$ & $35.85 \mathrm{a}$ & $14.15 \mathrm{a}$ & $12.27 \mathrm{a}$ & $14.15 \mathrm{a}$ & $12.27 \mathrm{a}$ \\
\hline $25 \mu \mathrm{g} / \mathrm{mL}$ & $2.35 d$ & $1.21 \mathrm{e}$ & $1.65 \mathrm{~d}$ & $0.38 \mathrm{c}$ & $1.02 \mathrm{c}$ & $0.98 \mathrm{~d}$ & $0.94 \mathrm{c}$ & $0.52 \mathrm{c}$ \\
\hline $50 \mu \mathrm{g} / \mathrm{mL}$ & $11.53 \mathrm{c}$ & $13.82 d$ & $13.42 \mathrm{c}$ & $12.82 b$ & $3.64 \mathrm{c}$ & $2.71 \mathrm{c}$ & $2.62 \mathrm{c}$ & $2.01 \mathrm{c}$ \\
\hline $75 \mu \mathrm{g} / \mathrm{mL}$ & $20.53 b$ & $17.41 \mathrm{c}$ & $18.47 \mathrm{~b}$ & $13.49 \mathrm{~b}$ & $8.74 b$ & $6.72 b$ & $7.63 b$ & $5.61 b$ \\
\hline $100 \mu \mathrm{g} / \mathrm{mL}$ & $41.01 \mathrm{a}$ & $39.91 \mathrm{a}$ & $40.18 \mathrm{a}$ & $33.41 \mathrm{a}$ & $14.65 \mathrm{a}$ & $12.46 \mathrm{a}$ & $13.38 \mathrm{a}$ & $10.47 \mathrm{a}$ \\
\hline LSD value at $P \leq 0.01$ & \multicolumn{4}{|c|}{ Fresh weight $\left(\mathrm{g}_{\text {plant }}{ }^{-1}\right)$} & \multicolumn{4}{|c|}{ Dry weight (g plant ${ }^{-1}$ ) } \\
\hline Control & - & - & - & - & - & - & - & - \\
\hline Fungicide & $24.91 \mathrm{a}$ & $20.83 a$ & $24.91 \mathrm{a}$ & $20.83 a$ & $4.09 \mathrm{~b}$ & $3.94 a$ & $4.09 \mathrm{a}$ & $3.94 a$ \\
\hline $25 \mu \mathrm{g} / \mathrm{mL}$ & $2.18 \mathrm{~d}$ & $1.02 \mathrm{c}$ & $1.13 \mathrm{~d}$ & $0.98 \mathrm{c}$ & $0.68 \mathrm{~d}$ & $0.53 b$ & $0.55 b$ & $0.43 b$ \\
\hline $50 \mu \mathrm{g} / \mathrm{mL}$ & $5.68 \mathrm{c}$ & $3.74 \mathrm{c}$ & $3.01 \mathrm{~d}$ & $2.15 \mathrm{c}$ & $1.13 \mathrm{~d}$ & $1.03 b$ & $1.10 \mathrm{~b}$ & $0.89 b$ \\
\hline $75 \mu \mathrm{g} / \mathrm{mL}$ & $11.58 \mathrm{~b}$ & $9.68 b$ & $8.16 \mathrm{c}$ & $7.77 \mathrm{~b}$ & $2.69 \mathrm{c}$ & $1.47 \mathrm{~b}$ & $1.54 \mathrm{~b}$ & $1.03 \mathrm{~b}$ \\
\hline $100 \mu \mathrm{g} / \mathrm{mL}$ & $25.74 a$ & $21.19 \mathrm{a}$ & $22.45 b$ & $18.94 a$ & $5.63 \mathrm{a}$ & $4.08 \mathrm{a}$ & $4.65 a$ & $3.11 \mathrm{a}$ \\
\hline LSD value at $P \leq 0.01$ & 2.31 & 3.19 & 2.32 & 2.74 & 1.01 & 1.52 & 1.12 & 1.18 \\
\hline
\end{tabular}

Means not sharing the same letters within a column differ significantly from each other at $P \leq 0.01$
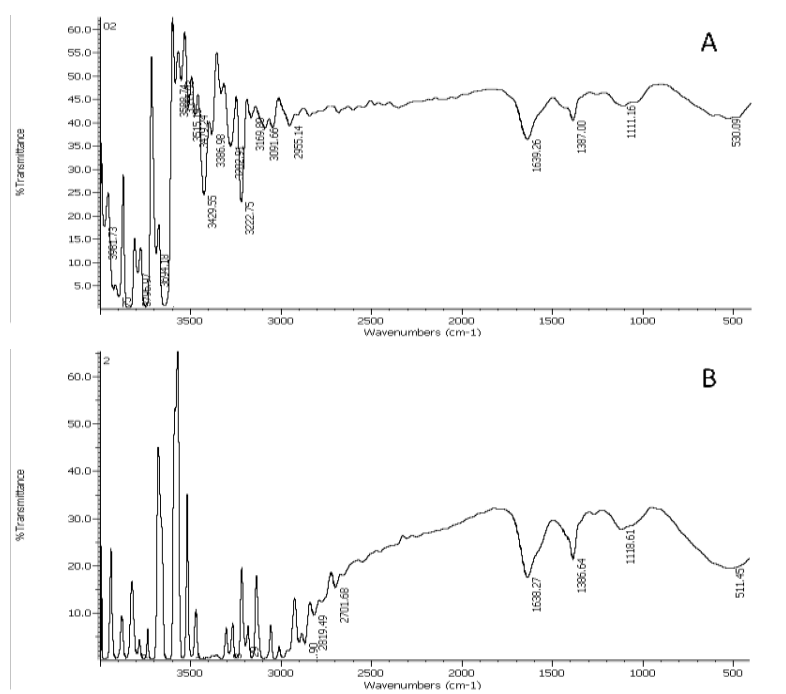

Fig. 4: FTIR spectra A: $M$. alba dried leaves; B: AgNPs synthesized using leaves extract of $M$. alba

recorded at 2819.49 and $3091.66 \mathrm{~cm}^{-1}$ are representing stretching vibrations of alkenes and alkyls $(\mathrm{C}-\mathrm{H})$. Whereas, the bands recorded at 1639.26 and $1638.27 \mathrm{~cm}^{-1}$ are showing C-N stretching (Fig. 4). Comparatively weak bands appearing between 511.45 and $530.09 \mathrm{~cm}^{-1}$ in FTIR spectra of dried leaves and AgNPs synthesized from leaves extract of white mulberry respectively showed the presence of halogen compounds. Bands at 1387 and $1386.64 \mathrm{~cm}^{-1}$ are indicating C-H bond with alkane's functional group. As can be seen in the Fig. 4A and B the peaks recorded at 1118.61 and $1111.16 \mathrm{~cm}^{-1}$ are representing the $\mathrm{C}-\mathrm{O}$ stretching. FTIR analysis of leaves and NPs synthesized from $A$. marmelos: FTIR spectra were acquired to trace potential biomolecules liable for effective stabilization and capping of inorganic (metal) nanoparticles synthesized by leaf extract of bael. The IR bands (Fig. 5A and B) recorded at 3196.78 and $344.51 \mathrm{~cm}^{-1}$ confirmed the presence of alkenes $\mathrm{C}=\mathrm{C}$ and alcohol (-OH). The band appearing at 2346.58 and 2344.11 $\mathrm{cm}^{-1}$ is assigning to $\mathrm{C}-\mathrm{O}$. The transmission bands at 1638.22 and $1630.89 \mathrm{~cm}^{-1}$ are corresponding to alkenes in aromatic compounds and amides (N-H). Whereas, the peak recorded at $1385.89 \mathrm{~cm}^{-1}$ shows stretching of iso-propyl group. The bands appearing at 1109.52 and $1065.83 \mathrm{~cm}^{-1}$ are confirming the existence of polysaccharides (Fig. 5A).

Merely few minor changes in the position of transmittance band between FTIR spectrum of AgNPs and phyto-extract were observed. Compounds present in phytoextract and participating in biosynthesis of AgNPs got confirmed with shifting of peaks. Reduction and stabilization of AgNPs were affected by plant extracted compounds comprising $\mathrm{CO}$ and $\mathrm{OH}$ groups that play a dynamic part in AgNPs' synthesis.

\section{SEM Analysis of synthesized AgNPs}

SEM image of the green synthesized AgNPs using leaves extract of white mulberry clearly indicates poly disperse spherical morphology. The average diameter of AgNPs ranged between 20-40 nm. However, in case of AgNPs synthesized using bael leaves are predominately spherical. The bio synthesized AgNPs are of comparatively larger size ranging up to $25-48 \mathrm{~nm}$ (Fig. 6). 


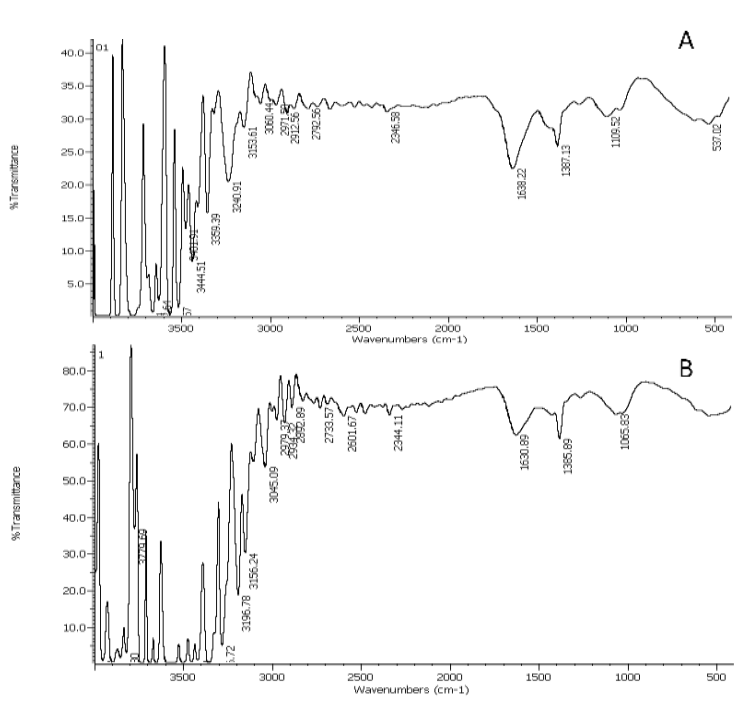

Fig. 5: FTIR spectra A: A. marmelos dried leaves; B: AgNPs synthesized using leaves extract of $A$. marmelos
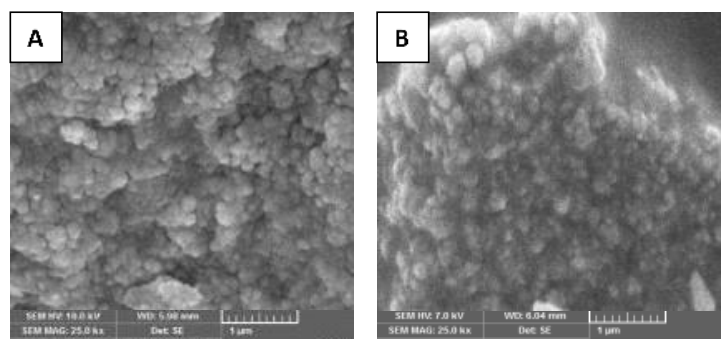

Fig. 6: Scanning electron microscope analysis of AgNPs synthesized from A: M. alba and B: A. marmelos

\section{Discussion}

This study confirms the potential of phyto-synthesized silver nanoparticles using bael and white mulberry leaf extracts in controlling soil borne fungal diseases in crops like tomato. Selection of white mulberry was carried out due to its excellent antimicrobial activities reported by many earlier workers (Ayoola et al. 2011; Zheng et al. 2013). It's extract has also shown significant inhibition of Fusarium oxysporum (Sharma and Trivedi 2002). Choice of bael fruit was also made on similar grounds as many earlier workers have validated antimicrobial potential in its different parts against both fungi and bacteria (Dhankhar et al. 2011; Rahman and Parvin 2014).

UV-Vis spectrophotometer was used to first confirm synthesis and presence of nanoparticles in the reaction mixture. Earlier literature showed that absorption between $400-450 \mathrm{~nm}$ is usually characteristic of silver NPs in the UV-Vis region (Sathishkumar et al. 2009; Ashraf et al. 2020). Clear peaks recorded at 413 and $410 \mathrm{~nm}$ in case of reaction mixture containing extracts of white mulberry and bael leaves thus followed the trend. Optimization trials showed maximum synthesis in reaction mixture possessing white mulberry a little earlier than in the reaction mixture supplemented with bael leaves extract. Optimum concentration of silver nitrate and $\mathrm{pH}$ were also found different for both plant extracts. The results were found consistent with the reports of Singh et al. (2009). Variation in parameters of NPs synthesis may be due to the variation in active biomolecules of both plants involved in reduction of silver ions into AgNPs. The mechanism and the cause of the conversion of $\mathrm{Ag}^{+}$into $\mathrm{Ag}$ nanoparticles are not very well understood. However, it is strongly anticipated that various functional groups existing in plant extracts might be the cause of this bio reduction of $\mathrm{Ag}^{+}$into AgNPs (Biswal and Misra 2020). Raja et al. (2012) and Rathi et al. (2015) documented the role of biomolecules such as C$\mathrm{O}$ and $-\mathrm{OH}$ in this kind of reduction during NPs synthesis. The presence of such related biomolecules was confirmed through FTIR. The size of AgNPs synthesized by using leaves extracts of white mulberry and bael fruit was recorded between $20-48 \mathrm{~nm}$ respectively with spherical morphology. Earlier findings also confirm variation in particle size with change in the source of nanoparticles' synthesis (Geethalakshmi and Sarada 2010).

Synthesized NPS showed significant antifungal potential against both selected soil borne phytopathogens with little variation. AgNPs synthesized using white mulberry leaves extract showed better results than that of synthesized using bael leaves. Size of synthesized NPs could be a reason for this variation, as small sized NPs are more efficient due to their easy uptake by the plants and their translocation in whole living system (Wang et al. 2013; Lv et al. 2018). Further reason of this variation might be the difference in attached biologically active components on the surface of synthesized NPs from the biological source. Hence selection of biological source for synthesis of NPs affects their antifungal potential. Both tested fungi also showed slight variation in their responses towards various treatments.

A reason for selecting nanoparticles to control soil borne pathogens in this work was the interesting mode of action of these nano sized particles. The efficacy of nano sized particles in comparison to their bulk materials is always higher due to the fact that the number of surface atoms rises with decrease in the particle size that in return increases the reactivity and hence several physical and chemical properties (Maurice and Hochella 2008; Hochella et al. 2008). The mechanism of $\mathrm{Ag}^{+}$ions to inhibit microbial growth is not well understood; however according to some scientists the negative charge present in the cell membrane of microbes interact with the positive charge of the $\mathrm{Ag}^{+}$ions in NPs (Dragieva et al. 1999; Stoimenov et al. 2002; Dibrov et al. 2002; Rawashdeh and Haik 2009). In a study conducted in 2004, Sondi and Salopek-Sondi (2004) established that the antimicrobial potential of AgNPs is dependent on their concentration and they also found this directly related to the pits formation in the cell walls of gram negative bacteria. Similarly, Kim et al. (2009) also validated the effect of nano $\mathrm{Ag}^{+}$on cell 
membranes of microbes, thus hampering their function and leading to cell death. Feng et al. (2000) reported that treatment of cells with $\mathrm{Ag}^{+}$results in loss of DNA ability to replicate, hence inactivation of expression of ribosomal subunit proteins, along with certain other cellular proteins and enzymes important for ATP production (Yamanaka et al. 2005). It is also known that plants treated with silver nanoparticles accumulate silver in form of highly stable nanoparticles that do not release ionic silver within the plant cells. Hence AgNPs are least toxic than its ionic form (Pak et al. 2017). Keeping all this information, the present study is providing a basis for the use of bio-synthesized NPs in disease management in fields. This will decrease reliance on synthetic pesticides providing a better ecofriendly approach.

\section{Conclusion}

Results of this study confirmed the potential of bael and white mulberry leaves extracts to synthesize antifungal, uniform and stable metallic nanoparticles that can significantly lower disease incidence of soil borne fungi in crops like tomato. Use of such phyto-synthesized silver nanoparticles can lower down the application of synthetic chemical fungicides in our agricultural soils.

\section{Author Contributions}

TA planned the whole work and provided lab facilities. NH and HA performed experimental work and WA helped in write up and statistical analysis.

\section{References}

Aritonang HF, H Koleangan, AD Wuntu (2019). Synthesis of silver nanoparticles using aqueous extract of medicinal plants' (Impatiens balsamina and Lantana camara) fresh leaves and analysis of antimicrobial activity. Intl J Microbiol 2019; Article 8642303

Arturo LI, LM Karla (2017). Fusarium oxysporum f. spp. lycopersici: How can we control this fungus? Adv Biotechnol Micro 4; Article 555637

Ashraf H, T Anjum, S Riaz, S Naseem (2020). Microwave assisted green synthesis and characterization of silver nanoparticles using Melia azedarach for the management of Fusarium wilt in tomato. Front Microbiol 11; Article 238

Ayoola OA, RA Baiyewu, JN Ekunola, BA Olajire, JA Egunjobi, EO Ayeni, OO Ayodele (2011). Phytoconstituent screening and antimicrobial principles of leaf extracts of two variants of Morus alba (s30 and s54). Afr J Pharm Pharmacol 5:2161-2165

Babu KS, K Ammani (2009). Antimicrobial activity of Morus alba. Asian J Biosci 4:124-126

Begum NA, S Mondal, S Basu, RA Laskar, D Mandal (2009). Biogenic synthesis of $\mathrm{Au}$ and $\mathrm{Ag}$ nanoparticles using aqueous solutions of Black Tea leaf extracts. Colloids Surf B Biointerf 71:113-118

Biswal AK, PK Misra (2020). Biosynthesis and characterization of silver nanoparticles for prospective application in food packaging and biomedical fields. Mater Chem Phys 250:123014

Chen HD, R Yada (2011). Nanotechnologies in agriculture: New tools for sustainable development. Trends Food Sci Technol 22:585-594

Dasgupta N, S Ranjan, D Mundekkad, C Ramalingam, R Shanker, A Kumar (2015). Nanotechnology in agro-food: From field to plate. Food Res Intl 69:381-400
Dhankhar S, S Ruhil, M Balhara, S Dhankhar, AK Chhillar (2011). Aegle marmelos (Linn.) Correa: A potential source of phytomedicine. $J$ Med Plant Res 5:1497-1507

Dibrov P, J Dzioba KK Gosink, CC Häse (2002). Chemiosmotic mechanism of antimicrobial activity of $\mathrm{Ag}^{+}$in Vibrio cholerae. Antimicrob Agents Chemother 46:2668-2670

Dragieva I, S Stoeva, P Stoimenov, E Pavlikianov, K Klabunde (1999). Complex formation in solutions for chemical synthesis of nanoscaled particles prepared by borohydride reduction process. Nanostruct Mater 12:267-270

EC (2012). Communication from the Commission to the European Parliament, the Council, the European Economic and Social Committee and the Committee of the Regions. 'A European strategy for Key Enabling Technologies - A bridge to growth and jobs'. Available at: http://eurlex.europa.eu/LexUriServ/LexUriServ.do?uri=COM: 2012:0341:FIN:EN:PDF (2012)

Erdogan MK (2020). Preparation and stabilization of Ag nanoparticles with $\mathrm{N}$-vinyl-2-pyrrolidone grafted-poly (vinyl alcohol) in an organic medium and investigation of their usability in the catalytic dye decolorization. Colloid Interf Sci Commun 34:100222

Feng QL, J Wu, GQ Chen, FZ Cui, TN Kim, JO Kim (2000). A mechanistic study of the antibacterial effect of silver ions on Escherichia coli and Staphylococcus aureus. J Biomed Mater Res 52:662-668

Geethalakshmi R, DVL Sarada (2010). Synthesis of plant-mediated silver nanoparticles using Trianthema decandra extract and evaluation of their anti microbial activities. Intl J Eng Sci Technol 2:970-975

Hochella MF, SK Lower, PA Maurice, RL Penn, N Sahai, DL Sparks, BS Twining (2008). Nanominerals, mineral nanoparticles and earth systems. Science 319:1631-1635

Huang J, G Zhan, B Zheng, D Sun, F Lu, Y Lin (2011). Biogenic silver nanoparticles by cacumen platyclade extract: Synthesis, formation mechanism, and antibacterial activity. Ind Eng Chem Res 50:9095-9106

Kim KJ, WS Sung, SK Suh, Moon, JS Choi, JG Kim, DG Lee (2009). Antifungal activity and mode of action of silver nano-particles on Candida albicans. BioMetals 22:235-242

Lv J, P Christie, S Zhang (2018). Uptake, translocation, and transformation of metal-based nanoparticles in plants: Recent advances and methodological challenges. Environ Sci Nano 6:41-59

Maurice PA, FH Michael (2008). Nanoscale particles and processes: A new dimension in soil science. Adv Agron 100:123-153

Mayek-Perez N, C Lopez-Castaneda, E Lopez-Salinas, J, CumpianGutierrez, IC Joaquın-Torres, JS Padilla-Ramırez, JA AcostaGallegos (2003). Effect of Macrophomina phaseolina (Tassi) Goid. on grain yield of common beans (Phaseolus vulgaris L.) and its relationship with yield stability parameters. Rev Mex Fitopatol $21: 168-175$

Merga G, R Wilson, GLynn, B Milosavljevic,D Meisel (2007). Redox catalysis on "naked" silver nanoparticles. J Phys Chem C 111:12220-12206

Michielse CB, M Rep (2009). Pathogen profile update: Fusarium oxysporum. Mol Plant Pathol 10:311-324

Pak ZH, N Karimi, H Abbaspour (2017). Effects of silver nanoparticle exposure on growth, physiological and biochemical parameters of Dracocephalum moldavica L. Iran J Plant Physiol 7:2173-2183

Parisi C, M Vigani, E. Rodriguez-Cerezo (2015). Agricultural nanotechnologies: What are the current possibilities? Nano Today 10:124-127

Rahman S, R Parvin (2014). Therapeutic potential of Aegle marmelos (L.)An overview. Asian Pac J Trop Dis 4:71-77

Raja K, A Saravanakumar, R, Vijayakumar (2012). Efficient synthesis of silver nanoparticles from Prosopis juliflora leaf extract and its antimicrobial activity using sewage. Spectrochim Acta A Mol Biomol Spectr $97: 490-494$

Rathi PR, M Reka, R Poovazhagi, M Kumar, K Murugesan (2015). Antibacterial and cytotoxic effect of biologically synthesized silver nanoparticles using aqueous root extract of Erythrina indica Lam. Spectrochim Acta A Mol Biomol Spectrsc 135:1137-1144

Rawashdeh R, Y Haik (2009). Antibactreial mechanisms of metallic nanoparticles - A review. Dyn Biochem Process Biotechnol Mol Biol $3: 12-20$ 
Sathishkumar M, K Sneha, SW Won, CW Cho, S Kim, YS Yun (2009). Cinnamon zeylanicum bark extract and powder mediated green synthesis of nano-crystalline silver particles and its bactericidal activity. Colloids Surf B Biointerfaces 73:332-338

Sharma N, PC Trivedi (2002). Screening of leaf extracts of some plants for their nematicidal and fungicidal properties against Meloidogyne incognita and Fusarium oxysporum. Asian J Exp Sci 16:21-28

Singh M, I Sinha, RK Mandal (2009). Role of $\mathrm{pH}$ in the green synthesis of silver nanoparticles. Mater Lett 63:425-427

Sondi I, B Salopek-Sondi (2004). Silver nanoparticles as antimicrobial agent: A case study on E. coli as a model for gram-negative bacteria. J Colloid Interface Sci 275:177-182

Srivastava AK, RB Singh (1990). Effect of organic amendment on interaction of Macrophomina phaseolina and Melpidogyne incognita on fresh bean (Phaseolus vulgaris). New Agric 1:99-100

Stoimenov P, R Klinger, GL Marchin, KJ Klabunde (2002). Metal oxide nanoparticles as bactericidal agents. Langmuir 18:6679-6686

Tolaymat T, A Genaidy, W Abdelraheem, D Dionysiou, C Andersen (2017). The effects of metallic engineered nanoparticles upon plant systems: An analytic examination of scientific evidence. Sci Tot Environ 579:93-106

Veena DR, HR Priya, RM Khatib, D Joythi (2014). Soil borne diseases in crop plants and their management. Res Rev J Agric Allied Sci 3:12-18
Vilchis-Nestor AR，V Sánchez-Mendieta, MA Camacho-López, RM Gómez-Espinosa, MA Camacho-López, J Arenas-Alatorre (2008). Solventless synthesis and optical properties of $\mathrm{Au}$ and $\mathrm{Ag}$ nanoparticles using Camellia sinensis extract. Mater Lett 62:3103-3105

Vincent JH (1947). Distortion of fungal hyphae in presence of certain inhibitor. Nature 159:850

Wang J, Y Koo, A Alexander, Y Yang, S Westerhof, Q Zhang (2013). Phytostimulation of poplars and Arabidopsis exposed to silver nanoparticles and $\mathrm{Ag}^{+}$at sublethal concentrations. Environ $\mathrm{Sci}$ Technol 47:5442-5449

Yamanaka M, K Hara, J Kudo (2005). Bactericidal actions of a silver ion solution on Escherichia coli, studied by energy-filtering transmission electron microscopy and proteomic analysis. Appl Environ Microbiol 71:7589-7593

Zheng LP, Z Zhang, LQ Xie, HY Yuan, YQ Zhang (2013). Antifungal activity of endophyte cultures of Morus Alba L. against phytopathogenic fungi. Adv Mater Res 641-642:615-618

Zubrod JP, M Bundschuh, G Arts, CA Brühl, G Imfeld, A Knäbel, S Payraudeau, JJ Rasmussen, J Rohr, A Scharmüller, K Smalling, S Stehle, R Schulz, RB Schäfer (2019). Fungicides: An overlooked pesticide class? Environ Sci Technol $53: 3347-3365$ 